\title{
JUM'AT BERSIH
}

\author{
NURWAHYUNI ANAS
}

9173770410159

nurwahyunianas16@gmail.com

1. Bentuk Kegiatan

$>$ Membersihkan masjid.

2. Lokasi

> Mesjid Al-Ikhlas, dusun Palloli desa Bontocini.

3. Hari/Tanggal dan Waktu

$>$ Jum'at, 23 oktober 2020 pukul 07:30 - 08:35

4. Peserta yang Dilibatkan

$>$ Mahasiswa KKLP Yapti Jeneponto.

5. Alasan Diadakannya

> Alasan diadakannya adalah karena melihat keadaan masjid yang kotor dan akan di laksanakan sholat jum'at maka kami para Mahasiswa berinisiatif membersihkan Masjid tersebut.

6. Tujuan dan Manfaat

> Tujuan dan Manfaatnya adalah untuk membersihkan Masjid agar supaya Masyarakat Desa Bontocini dapat beribadah dengan nyaman.

7. Deskripsi Kegiatan

> Kegiatan membersihkan Masjid ini dilakukan pada pagi hari , sebelum dilaksanakannya sholat jum'at. Dimulai dari membersihkan area dalam masjid sampai kepekarangannya. 